\title{
Stabilizing a DNA Three-Way Junction by Insertion of $N^{4}$-Aryl-2-deoxy-5-methylcytidines
}

\author{
Omar M. Ali and Erik B. Pedersen* \\ Department of Chemistry, Odense University, DK-5230 Odense M, Denmark
}

\begin{abstract}
Ali, O. M. and Pedersen, E. B., 1999. Stabilizing a DNA Three-Way Junction by Insertion of $N^{4}$-Aryl-2-deoxy-5-methylcytidines. - Acta Chem. Scand. 53: 497-507. (C) Acta Chemica Scandinavica 1999.

4,4'-Dimethoxytrityl and acetyl sugar protected $\alpha$ and $\beta$ thymidines are converted into the corresponding $N^{4}$-aryl-2-deoxy-5-methylcytidines via $4-(2,4,6-$ trimethylbenzenesulfonyloxy) pyrimidin-2(1H)-one nucleosides. These compounds were used for DNA synthesis after deacetylation and phosphitylation. Increased melting temperatures $\left(6.2-9.6^{\circ} \mathrm{C}\right)$ of three-way junctions (TWJ) were observed when $N^{4}$-(2-anilinophenyl)-, $N^{4}$-(2-benzylphenyl)- or $N^{4}$-(2-fluorenyl)2-deoxy-5-methylcytidines were inserted into the middle of the junction region. A $26.6^{\circ} \mathrm{C}$ increase in melting temperature was observed using $\alpha$ nucleosides in one of the strands of TWJ and with insertion of 2-deoxy- $N^{4}$-(2-fluorenyl)-5methyl- $\alpha$-cytidine at the junction. A large increase in thermal melting $\left(18.8^{\circ} \mathrm{C}\right)$ of the TWJ was also observed when 2-deoxy-5-methyl- $N^{4}$-(4-phenoxyphenyl)- $\alpha$ cytidine was inserted at the junction as a chimeric nucleoside into a strand of $\beta$ nucleosides.
\end{abstract}

Synthetic oligodeoxynucleotides (ODNs) have been widely employed to modulate the biological activity of DNA and RNA. ${ }^{1-5}$ Many attempts have been made to synthesize ODNs with higher stability towards the nuclease, stronger affinity and specificity towards the complementary sequences and better ability to penetrate the cell membrane. $^{2,4,6}$ It has been shown that the covalent binding of an $\mathrm{N}$-2-acetylaminofluorene (AAF) residue in a bulged guanine increases the melting temperature of the heteroduplex up to $15^{\circ} \mathrm{C}$ depending on the position of the modified guanine in the run. ${ }^{7,8}$ The group of Patel ${ }^{9}$ studied the carcinogenic aminofluorene covalently attached to the duplex by NMR spectroscopy, showing that a covalent aminofluorene- $\mathrm{C}^{8}$-deoxyguanosine adduct intercalated into the helix between flanking $\mathrm{dG}-\mathrm{dC}$ pairs opposite to a deletion site. Intercalation of the aminofluorene ring, resulting in displacement of the modified deoxyguanosine ring into the major groove, has also been reported by others. ${ }^{10}$ The group of Hélène ${ }^{11}$ studied the hybridization of $17 \mathrm{mer}$ ODN with a $36 \mathrm{mer}$ hairpin structure DNA forming a three-way junction (TWJ) which exhibited slightly stronger binding than an ODN with two sections of complementary sequence separated by a bulged sequence which could not form a hairpin. TWJs were studied when one, two or more unpaired bases were located at the branch point. This did not result in improved stabilization. ${ }^{12,13}$ Formation of a TWJ was confirmed by NMR studies on complexes

\footnotetext{
* To whom correspondence should be addressed.
}

with two unpaired bases at the branch point. ${ }^{14,15}$ The NMR work indicated preferred base coaxial stacking across the branch point. A lot of work has been done to develop a class of antisense ODNs that would display affinity to complementary DNA and RNA sequences and still be resistant to nucleases. Alternating $\alpha, \beta$ ODNs with alternating $3^{\prime}-3^{\prime}$ and $5^{\prime}-5^{\prime}$ phosphodiester linkages were proposed several years ago. ${ }^{16} \mathrm{UV}$ thermal denaturation and gel electrophoresis studies have shown that stable duplexes can be found on targeting ODNs containing multiple polarity reversals, which were generated by combination of $3^{\prime}-3^{\prime}$ and $5^{\prime}-5^{\prime}$ phosphodiester bonds to the complementary DNA and RNA sequences. ${ }^{17}$ Boiziau et $a .^{18}$ illustrated the potential of antisense properties of chimeric ODNs by their involvement in $\mathrm{R}$ Nase $\mathrm{H}$-mediated arrest of reverse transcription in vitro. $\alpha$-Oligonucleotides are of interest in antisense therapy because of their improved hybridization properties to target nucleic acids together with their stability towards nuclease degradation. ${ }^{19}$ We found improved stabilization when 2-deoxy-5-methyl- $N^{6}$-pyrenylmethylcytidine was inserted at the junction region of a $\mathrm{TWJ},{ }^{20}$ and also when it was inserted as its chimeric $\alpha$ anomer. ${ }^{21,22} \mathrm{We}$ have now begun a search for other potential intercalators which may possibly further stabilize the TWJ.

\section{Results and discussion}

Synthesis of intercalating monomers. The phosphoramidites $\mathbf{5 a - c}$ were synthesized as shown in Scheme 1. The 


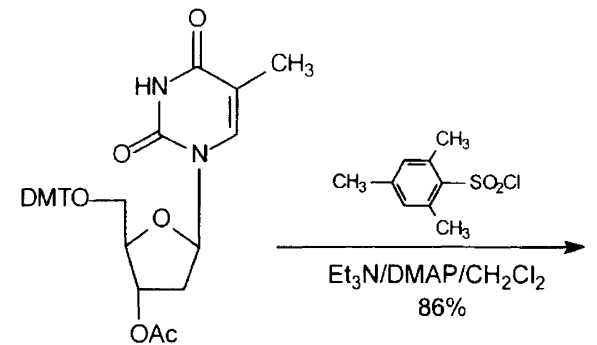

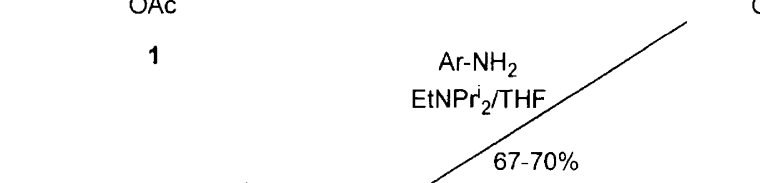<smiles>CCCCOc1nc(=O)n(C2CC3OC2C(COC)C3OC(C)=O)cc1C</smiles>

2<smiles>[R17]Nc1nc(=O)n(C2CC(O[P+](F)(F)F)C(COC)O2)cc1C</smiles>

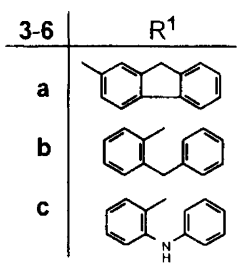

DMT $=4,4^{\prime}$-Dimethoxytrityl

\section{Scheme 1.}

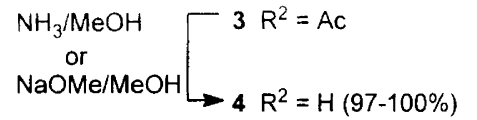<smiles>CCNc1nc(=O)n(C2CC(O)C3CC2O3)cc1C</smiles>

6 a-c $(X)$
5

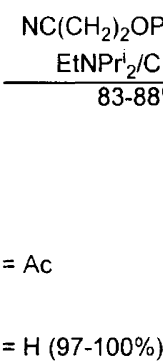

protected nucleoside $3^{\prime}$ - $O$-acetyl-2'-deoxy-5'-O-(dimethoxytrityl) thymidine ${ }^{20}(1)$ was allowed to react overnight with 2,4,6-trimethylbenzenesulfonyl chloride in the presence of triethylamine and 4-dimethylaminopyridine (DMAP) in dichloromethane at room temperature to give the $O^{4}$-thymidine derivative 2 in $86 \%$ yield after column chromatography. The $N^{4}$-cytidine derivatives 3a-c were synthesized in $67-70 \%$ yield by refluxing 2 aminofluorene, 2-aminodiphenylamine or 2-aminodiphenylmethane with the $O^{4}$-thymidine derivative 2 in tetrahydrofuran (THF) in the presence of $\mathrm{N}, \mathrm{N}$ diisopropylethylamine for $36 \mathrm{~h}$ followed by column chromatographic purification. We attempted to introduce the aromatic amines to obtain $N^{4}$-cytidine derivatives via the corresponding 4-triazolyl derivative ${ }^{20}$ in different solvents, such as THF, isopropyl alcohol and $N, N$-dimethylforamide (DMF) but no reaction was observed. Deacetylation of the compounds $\mathbf{3 b}, \mathbf{c}$ were carried out with sodium methoxide in methanol for $1 \mathrm{~h}$ to give the free 3'-OH-nucleosides $\mathbf{4 b}, \mathbf{c}$ in quantitative yield while $\mathbf{3 a}$ was deacetylated using saturated ammonia in methanol overnight to give $\mathbf{4 a}$ in $97 \%$ yield. Phosphitylation of $\mathbf{4}$ to give 5 in $83-88 \%$ yield was achieved by reaction with 2-cyanoethyl $\mathrm{N}, \mathrm{N}$-diisopropylchlorophosphoramidite in the presence of $N, N$-diisopropylethylamine according to a standard procedure. ${ }^{20}$ The purity of the phosphoramidite derivatives $\mathbf{5 a}-\mathbf{c}$ was $100 \%$ according to ${ }^{31} \mathrm{P}$ NMR spectroscopy.

The synthesis of the phosphoramidite $\mathbf{1 1}$ for the synthesis of $\alpha$ DNAs was accomplished in a similar way (Scheme 2) to the $\beta$ nucleoside phosphoramidites 5 . The overall yield of the phosphoramidite 11 was $49 \%$ starting from the corresponding protected $\alpha$ nucleoside, which was synthesized as previously described. ${ }^{22}$

While the phosphoramidite $\mathbf{1 1}$ is suitable for the synthesis ODNs where the nucleosides are all $\alpha$ anomers, 


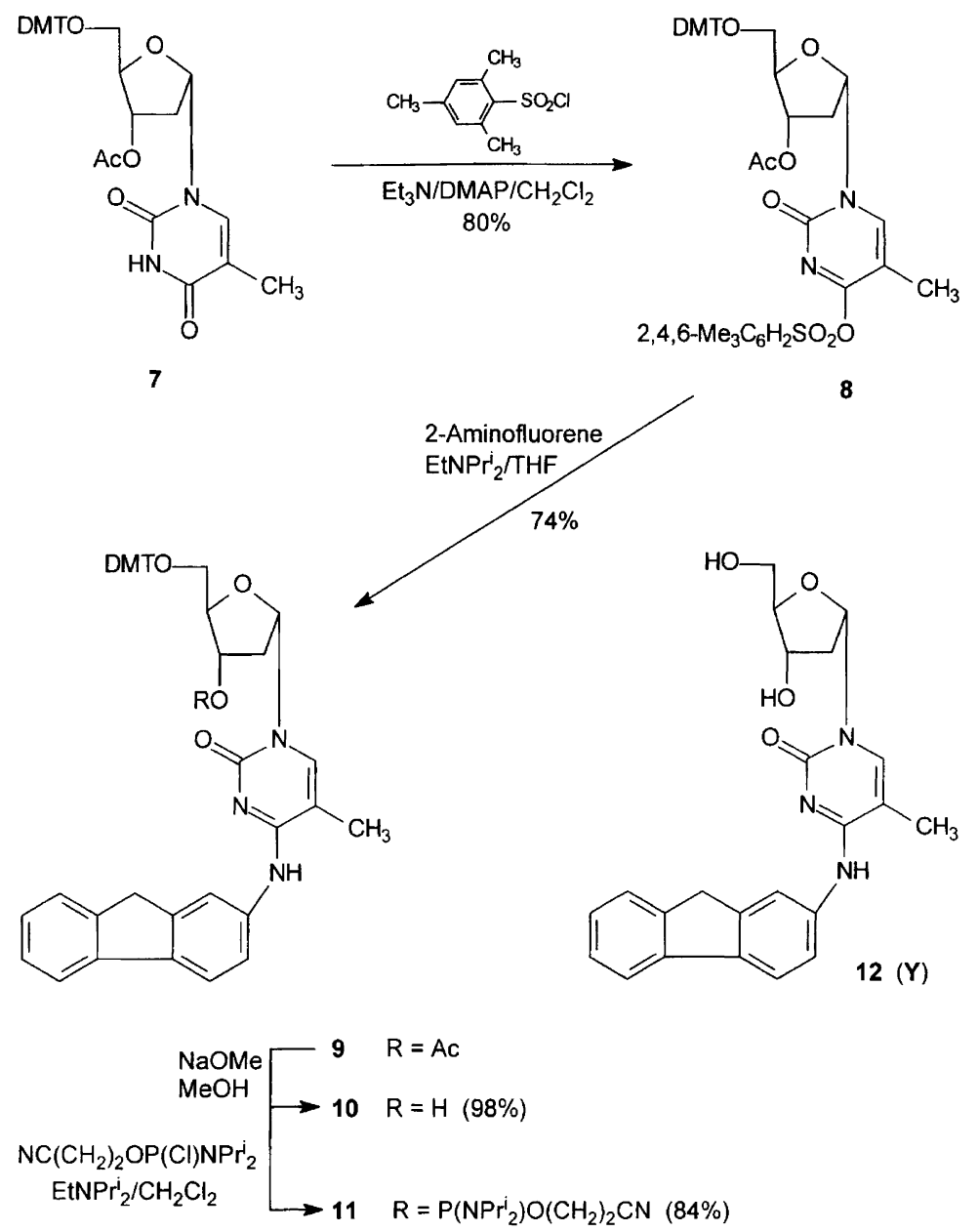

DMT $=4,4^{\prime}-$ Dimethoxytrity

Scheme 2.

the $3^{\prime}$ and $5^{\prime}$ protecting groups in $\mathbf{1 1}$ have to be interchanged in order to synthesize alternating $\alpha, \beta$ ODNs where $\alpha$ nucleosides are connected to the natural $\beta$ strands through $3^{\prime}-3^{\prime}$ and $5^{\prime}-5^{\prime}$ phosphodiester bonds. The appropriate starting material $\mathbf{1 3}^{\mathbf{2 1}}$ was used in a similar synthetic sequence (Scheme 3 ) as outlined for the amidites 5 and 11 and the phosphoramidite 17 was obtained in $49 \%$ overall yield.

Synthesis of oligodeoxynucleotides. According to the phosphoramidite methodology, ${ }^{23}$ both modified and unmodified ODNs were synthesised on a Pharmacia Gene Assembler Special ${ }^{\circledR}$ DNA-synthesizer on a $0.2 \mu \mathrm{mol}$ scale. 6-min couplings were used in order to achieve high coupling efficiencies for the modified phosphoramidites whereas 2-min couplings were used for the commercial ones. The efficiency of each coupling step was monitored by release of dimethoxytrityl cation after each step. Removal from the solid support and deprotection was carried out at room temperature for 4 days in
$25 \%$ ammonia. All ODNs were desalted using Pharmacia NAP-10 columns.

For the synthesis of the appropriate $\alpha$ ODN sequences it was assumed that, in duplexes, they would bind in a parallel orientation with respect to their complementary $\beta$-sequences. ${ }^{24}$ It was convenient to use a $\beta \mathrm{T}$-support and it is believed that the extra $(\beta T)$ mismatching nucleoside at the $3^{\prime}$-end does not contribute to the differences in the stabilities of the TWJ within a series of $\alpha$ ODNs. The commercially available Biogenex universal CPG support was used for the ODN synthesis when the modified nucleoside was at the 3 '-end of the targeting $\alpha$ ODN. The universal CPG support was deprotected using $2 \% \mathrm{LiCl}-\mathrm{NH}_{4} \mathrm{OH}$. For the synthesis of $\alpha$ ODNs and chimeric ODNs the $2^{\prime}$-deoxy-5-methyl- $\alpha$-cytidine amidite $19^{22}$ and the $\alpha$-thymidine amidite $\mathbf{2 0}^{21}$ (Fig. 1), respectively, were used.

Targeting $\beta$ ODNs. In general, branched structures in RNA are structure elements with a more or less perman- 
<smiles>CC(=O)OCC1OC2CC(O[C@H](C)OC(C)=O)C1C2</smiles>

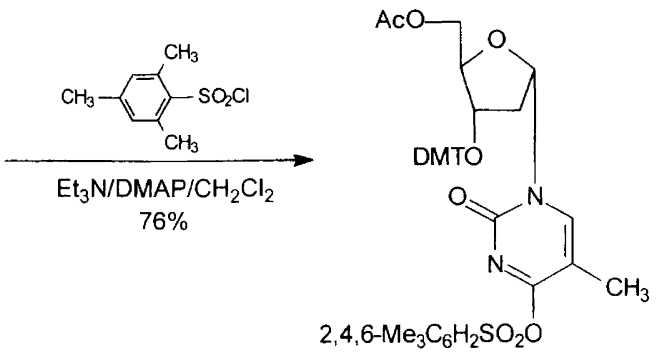

14

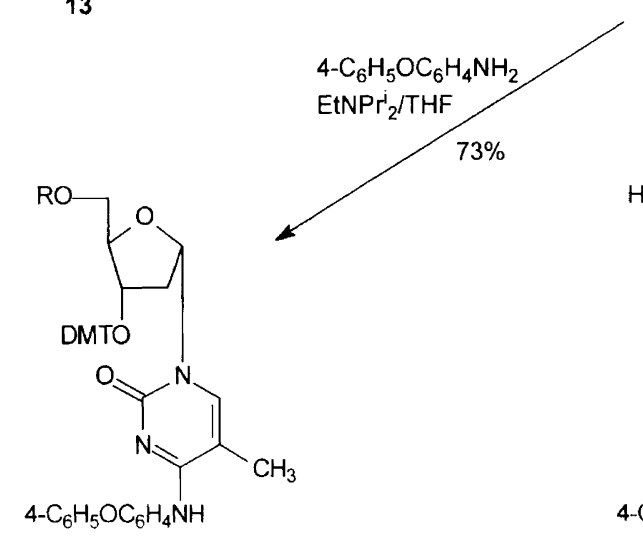<smiles>CCCCOCCOCCCO</smiles>

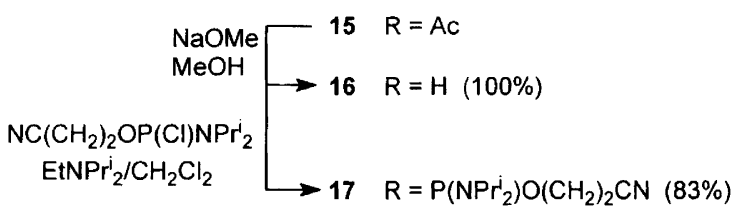

$18(Z)$

DMT $=4,4^{\prime}$-Dimethoxytrityl

Scheme 3.

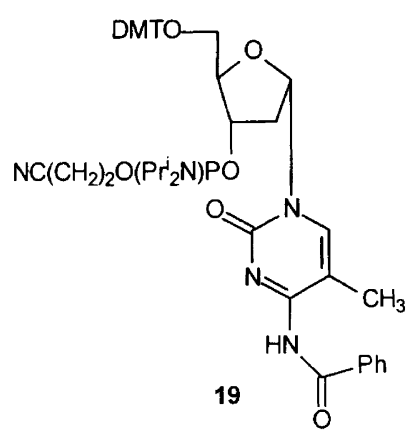

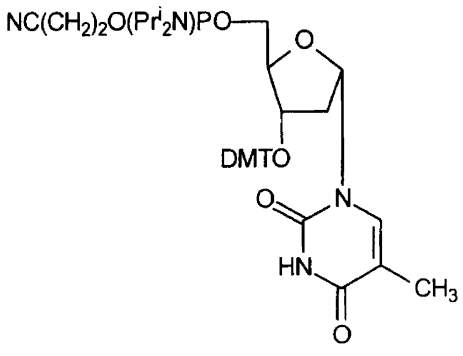

20

DMT $=4,4^{\prime}$-Dimethoxytrityl

Fig. 1.

ent existence whereas DNA branched structures are formed as intermediates in a process leading to DNA rearrangement. One can use DNA TWJs as a convenient model to study the intercalation effect. In this study we used a DNA TWJ formed from a 36mer hairpin ODN and an $17 \mathrm{mer}$ ODN as previously described by Francois et $a l .{ }^{11}$ The ability of the $17 \mathrm{mer}$ ODN, containing the modified bulges, to hybridize with the target hairpin is summarized in Table 1. The stability of the TWJ is dependent on the conjugated intercalating moiety and its regional position at the TWJ.

The largest $T_{\mathrm{m}}$ was observed for all the intercalators used when the intercalating moiety was inserted into the position 2 in the middle of the TWJ. The $T_{\mathrm{m}} \mathrm{s}$ of the 
Table 1. Thermal melting data $T_{\mathrm{m}} /{ }^{\circ} \mathrm{C}\left(\Delta T_{\mathrm{m}} /{ }^{\circ} \mathrm{C}\right)$ of TWJ and the corresponding duplex (deletion of the stem loop region in the TWJ) when inserted at positions 1-3 using the modified nucleoside 6.

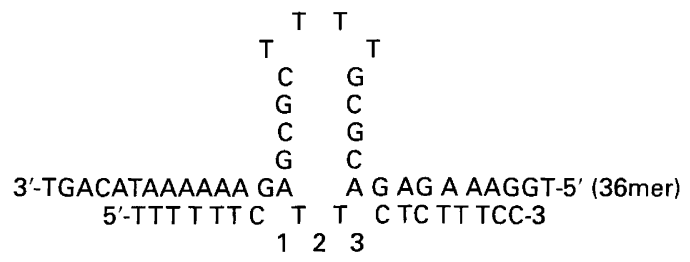

3'-TGACATAAAAAA GA A G AG A AAGGT-5 5 -TTT T TT C T T C TC TT TCC-3

\begin{tabular}{|c|c|c|c|c|c|c|c|}
\hline \multirow[b]{2}{*}{ Sequence } & \multirow{2}{*}{$\begin{array}{l}\text { Insertion } \\
\text { position }\end{array}$} & \multicolumn{3}{|c|}{ TWJ: $T_{\mathrm{m}} /{ }^{\circ} \mathrm{C}\left(\Delta T_{\mathrm{m}} /{ }^{\circ} \mathrm{C}\right)$} & \multicolumn{3}{|c|}{ Duplex: $T_{\mathrm{m}} /{ }^{\circ} \mathrm{C}\left(\Delta T_{\mathrm{m}} /{ }^{\circ} \mathrm{C}\right)$} \\
\hline & & $X=6 a$ & $X=6 b$ & $X=6 c$ & $X=6 a$ & $X=6 b$ & $X=6 c$ \\
\hline 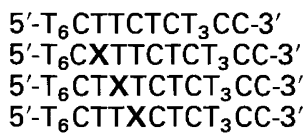 & $\begin{array}{l}- \\
1 \\
2 \\
3\end{array}$ & $\begin{array}{l}26.8- \\
30.4(3.6) \\
36.4(9.6) \\
33.2(6.4)\end{array}$ & $\begin{array}{l}26.8- \\
29.4(2.6) \\
32.6(6.2) \\
30.2(2.2)\end{array}$ & $\begin{array}{l}26.8- \\
29.4(2.6) \\
33.0(6.8) \\
29.0(1.8)\end{array}$ & $\begin{array}{l}48.2-\overline{-} \\
42.2(-6.0) \\
41.8(-6.4) \\
42.2(-6.0)\end{array}$ & $\begin{array}{l}48.2-\overline{7.4} \\
40.8(-7.4) \\
40.8(-7.4) \\
40.8(-7.4)\end{array}$ & $\begin{array}{l}48.2-\overline{-} \\
40.4(-7.8) \\
41.2(-7.0) \\
41.6(-6.6)\end{array}$ \\
\hline
\end{tabular}
123

bulged fluorenyl nucleoside $\mathbf{6 a}$ were higher than the corresponding ones of the other two intercalators $(\mathbf{6 b}$ and $\mathbf{6 c}$ ).

The effect of the conjugated intercalator on the TWJ stabilization was compared with the effect of the corresponding duplex stabilization (Table 1) obtained by deletion of the stem of the hairpin. Compared with the natural duplex, clear destabilization of the duplex $\left(\Delta T_{\mathrm{m}}=\right.$ -6.0 to $-7.8^{\circ} \mathrm{C}$ ) was observed when the bulged intercalating moieties were at the same positions in the $17 \mathrm{mer}$ ODN.

Over the last decade, there has been a great deal of interest in the conjugation of DNA intercalators to triple helix forming ODNs in order to stabilize the triplex under physiological conditions. The modified oligos were also used against the target shown in Table 2 in order to investigate whether the nucleoside modifications used in the present work were suitable for stabilizing a triplex. In order to investigate the effect of $\mathrm{pH}$ it was adequate to use an acetate buffer. Using absorption spectroscopy

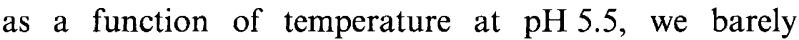
observed two transitions (triplex and target duplex) because they are very close together. But at $\mathrm{pH} 6.0$ and $\mathrm{pH} 6.5$ (Table 2), the two transitions are clearly distinguished, the higher one due to the dissociation of the double-stranded target while the lower one existed only in the presence of the triplex forming ODN. The melting temperature of the target duplex is $\mathrm{pH}$ independent while the $T_{\mathrm{m}}$ of the triplex-forming $\mathrm{ODN}$ is strongly $\mathrm{pH}$ dependent, with the $T_{\mathrm{m}}$ of the triplex decreasing ca. $13^{\circ} \mathrm{C}$ when the buffer was changed from $\mathrm{pH} 6.0$ to $\mathrm{pH} 6.5$. In general small positional or sequence-specific changes in the triplex stabilities were observed in case of $6 \mathbf{a}\left(\Delta T_{\mathrm{m}}=\right.$ -2.4 to $2.8^{\circ} \mathrm{C}$ at $\mathrm{pH} 6.5$ ). As in a previous investigation by Rougée et al. $^{25}$ we observed no hysteresis at $\mathrm{pH} 6.0$. At $\mathrm{pH} 6.5$, we observed a hysteresis of $2.0-5.2^{\circ} \mathrm{C}$ when the conjugated aminofluorene nucleoside was inserted. For the modified nucleosides $\mathbf{6 b}, \mathbf{c}$ we observed a slightly lower $T_{\mathrm{m}}$ for the triplexes with the modified ODNs when compared with the $T_{\mathrm{m}}$ of the natural triplex. Again for these nucleosides we observed a hysteresis $\left(2.8-3.6^{\circ} \mathrm{C}\right)$ for the modified ODNs in a phosphate buffer at $\mathrm{pH} 6.3$ (data not shown).

Targeting $\alpha$ ODNs. On targeting an $\alpha$ ODN to the flanks of a hairpin to form a TWJ (entry 2, Table 3) we observed remarkable stabilization as measured by an increase of the melting point $\left(15.2^{\circ} \mathrm{C}\right)$ compared with a natural targeting ODN (entry 1). A promising result with $\Delta T_{\mathrm{m}}=$ $26.6^{\circ} \mathrm{C}$ was obtained when $N^{4}$-fluorenyl-5-methyl- $\alpha$ cytidine (12) was inserted as $\mathbf{Y}$ into the targeting $\alpha$-strand (entry 4) in the middle of the TWJ. The increase in $T_{\mathrm{m}}$ was also remarkable on insertion of $\mathbf{Y}$ at the adjacent sites. Stable duplexes were formed when short $\alpha$ ODNs were allowed to hybridize to the $5^{\prime}$-flank of the hairpin (entries 6-9). The largest increase $\left(\Delta T_{\mathrm{m}}=26.8^{\circ} \mathrm{C}\right)$ for

Table 2. Thermal melting data $T_{\mathrm{m}} /{ }^{\circ} \mathrm{C}\left(\Delta T_{\mathrm{m}} /{ }^{\circ} \mathrm{C}\right)$ of triplexes with insertions into the triplex forming ODN using $6 \mathrm{a}$ at $\mathrm{pH} 6.0$ and 6.5, and $6 \mathrm{~b}, \mathrm{c}$ at $\mathrm{pH} 6.3$.

5'-TGACATA $\mathrm{GA}_{2} \mathrm{GAGA}_{3} \mathrm{G}_{2}$ T-3

\begin{tabular}{|c|c|c|c|c|c|}
\hline Sequence & $\begin{array}{l}\text { 6a, } \mathrm{pH} 6.0 \\
T_{\mathrm{m}}\left(\Delta T_{\mathrm{m}}\right) /{ }^{\circ} \mathrm{C} \\
\left(10-80^{\circ} \mathrm{C}\right)\end{array}$ & $\begin{array}{l}\text { 6b, } \mathrm{pH} 6.5 \\
T_{m}\left(\Delta T_{m}\right) /{ }^{\circ} \mathrm{C} \\
\left(10-80^{\circ} \mathrm{C}\right)\end{array}$ & $\begin{array}{l}\text { 6a, pH } 6.5 \\
T_{\mathrm{m}} /{ }^{\circ} \mathrm{C} \\
\left(80-10^{\circ} \mathrm{C}\right)\end{array}$ & $\begin{array}{l}6 \mathbf{b}, \mathrm{pH} 6.3 \\
T_{\mathrm{m}} /{ }^{\circ} \mathrm{C} \\
\left(10-80^{\circ} \mathrm{C}\right)\end{array}$ & $\begin{array}{l}6 \mathrm{c}, \mathrm{pH} 6.3 \\
T_{\mathrm{m}} /{ }^{\circ} \mathrm{C} \\
\left(10-80^{\circ} \mathrm{C}\right)\end{array}$ \\
\hline $\begin{array}{l}5^{\prime}-\mathrm{T}_{6} \mathrm{CTTCTCT}_{3} \mathrm{CC}^{\prime} 3^{\prime} \\
5^{\prime}-\mathrm{T}_{6} \mathrm{CXTTCTCT}_{3} \mathrm{CC}^{\prime} \mathrm{3}^{\prime} \\
5^{\prime}-\mathrm{T}_{6} \mathrm{CTXTCTCT}_{3} \mathrm{CC}^{\prime} \mathrm{3}^{\prime} \\
5^{\prime}-\mathrm{T}_{6} \mathrm{CTTXCTCT}_{3} \mathrm{CC}^{\prime} \mathbf{3}^{\prime}\end{array}$ & $\begin{array}{l}48.2 \\
49.8 \quad(1.6) \\
47.0(-1.2) \\
46.2(-2.0)\end{array}$ & $\begin{array}{lr}35.4 & \\
38.2 & (2.8) \\
34.2 & (-1.0) \\
33.0 & (-2.4)\end{array}$ & $\begin{array}{l}34.6 \\
33.0 \\
32.2 \\
30.2\end{array}$ & $\begin{array}{l}28.6 \\
26.0 \\
26.8 \\
26.0\end{array}$ & $\begin{array}{l}28.6 \\
26.8 \\
28.4 \\
26.8\end{array}$ \\
\hline
\end{tabular}
$3^{\prime}-\mathrm{ACTGTAT}_{6} \mathrm{CT}_{2} \mathrm{CTCT}_{3} \mathrm{C}_{2} \mathrm{~A}-5^{\prime}$ 
Table 3. Thermal melting data $T_{\mathrm{m}} / \mathrm{C}\left(\Delta T_{\mathrm{m}} /{ }^{\circ} \mathrm{C}\right)$ of Table 1 type TWJs and duplexes when using $\alpha$ ODNs; and of duplexes with the half hairpin 3'-TTGCGCAGAGAAAGGT-5'. Insertions $Y=12$ at positions 1-3. C is 2-deoxy-5-methyl- $\alpha$-cytidine.

\begin{tabular}{|c|c|c|c|c|c|}
\hline Entry & Sequence & $\begin{array}{l}\text { Insertion } \\
\text { position }\end{array}$ & $\begin{array}{l}\text { TWJ } \\
T_{\mathrm{m}}\left(\Delta T_{\mathrm{m}}\right) /{ }^{\prime \prime} \mathrm{C}\end{array}$ & $\begin{array}{l}\text { Duplex: } \\
T_{\mathrm{m}}\left(\Delta T_{\mathrm{m}}\right) / \mathrm{C}\end{array}$ & $\begin{array}{l}\text { Half } \\
\text { hairpin }\end{array}$ \\
\hline 1 & 5'- $\beta$-(TTTTTTTCTTCTTTCC)-3' & - & $30.0-$ & $47.8-$ & \\
\hline 2 & 3'- $\beta$ T- $\alpha$-(TTTTTTCTTCTCTTTCC)-5' & - & $45.2(15.2)$ & $58.0(10.2)$ & \\
\hline 3 & $3^{\prime}-\beta T-\alpha$-(TTTTTTCYTTCTCTTTCC)-5' & 1 & $52.6(22.6)$ & $56.4 \quad(8.6)$ & \\
\hline 4 & $3^{\prime}-\beta T-\alpha$-(TTTTTTCTYTCTCTTTCC)-5' & 2 & $56.6(26.6)$ & $57.2(9.4)$ & 49.0 \\
\hline 5 & $3^{\prime}-\beta T-\alpha$-(TTTTTTCTTYCTCTTTCC)-5' & 3 & $48.8(18.8)$ & $54.8(7.0)$ & \\
\hline 6 & $5^{\prime}-\beta$-(TCTCTTTCC)- $3^{\prime}$ & - & $32.0-$ & & 28.2 \\
\hline 7 & $3^{\prime}-\alpha-($ YTTCTCTTTCC)-5' & 1 & $50.4(18.4)$ & & \\
\hline 8 & $3^{\prime}-\alpha-($ YTCTCTTTCC $)-5^{\prime}$ & 2 & $58.8(26.8)$ & & 53.0 \\
\hline 9 & $3^{\prime}-\alpha-($ TYCTCTTTCC)-5' & 3 & $48.8(16.8)$ & & \\
\hline
\end{tabular}

the melting was obtained when the modified base was added to the 3 '-end of the targeting $\alpha$ ODN in the middle of the junction (entry 8 ). This stability is probably due to the intercalating moiety and the continuous coaxial stacking of the right foot and the stem of the hairpin.

The stabilization of the TWJ was compared with the stabilization of the corresponding duplex obtained by deletion of the stem of the TWJ hairpin. For duplexstranded 24 mer DNA the unmodified $x$ ODN (entry 2) hybridizes better than the corresponding complementary $\beta$ ODN (entry 1) with $\Delta T_{\mathrm{m}}=10.2^{\circ} \mathrm{C}$. Incorporation of fluorenyl-modified base in the $\alpha$-strand of the duplex (entries 3-5) results in destabilization of approximately $0.8-3.2{ }^{\circ} \mathrm{C}$ compared with the $\alpha$-sequence (entry 2 ). Further destabilization $\left(2.8-6.8^{\circ} \mathrm{C}\right.$, data not shown) was observed when 2-deoxy-5-methyl- $\alpha$-cytidine inserted instead of its conjugated analog.

It was necessary to be sure that the hybridization of Y-18mer or Y-9mer with the hairpin was due to the TWJ formation and not to simple duplexes formed by hybridization to the 5'-flank side of the hairpin. This side is believed to form the more stable duplexes because of the $\mathrm{C}-\mathrm{G}$ base pairs. If there were hybridization to the 5 -flank of the hairpin only, the duplex would have had dangling ends to the $3^{\prime}$-side. In Table 3 the ODNs from entries 4,6 and 8 are hybridized against the $5^{\prime}$ half of the $36 \mathrm{mer}$ hairpin. This corresponds to a shortening of an eventually dangling end of the 36 mer. If a TWJ were not formed in the first place with the hairpin of Table 1, no change in $T_{\mathrm{m}}$ would have been expected on replacing the hairpin with the half hairpin. However, when the melting data for half duplexes are compared with those of the corresponding TWJs, the TWJ formation is confirmed.

Targeting chimeric ODNs. Formation of a stable duplex that contained a parallel segment embedded in an overall antiparallel helix was observed ${ }^{26}$ upon incorporation of $\alpha-T$ in otherwise fully $\beta$-DNA using $3^{\prime}-3^{\prime}$ and $5^{\prime}-5^{\prime}$ phosphodiester linkages to invert the strand polarity to provide a local parallel-stranded environment. Appropriately protected $\alpha-2^{\prime}$-deoxyribonucleotides 17 and 20 together with commercial $\beta$-2'-deoxyribonucleoside 3'-phosphoramidites were used to synthesise chimeric $\alpha, \beta$ ODNs with $3^{\prime}-3^{\prime}$ and $5^{\prime}-5^{\prime}$ internucleotide phosphodiester linkages.

It is obvious that the hybridization of chimeric $\alpha, \beta$ ODNs (entries 12-15) with the hairpin complex (Table 4) is stabilized more $\left(\Delta T_{\mathrm{m}}=11.6-18.8^{\circ} \mathrm{C}\right)$ than the hybridization of the natural ODN (entry 10) and this is due to the insertion of phenoxyphenyl conjugated $\alpha$ nucleoside into the TWJ region. The large increases in thermal stability are rather remarkable when compared with those previously reported for the corresponding phenoxyphenyl conjugated $\beta$ nucleoside. ${ }^{27}$ For the same hairpin ODN, when hybridized with the corresponding modified complementary $\beta$ ODN containing the corresponding intercalating $\beta$-nucleoside and normal $3^{\prime}-5^{\prime}$ phosphodiester linkages, only a $9.0^{\circ} \mathrm{C}$ increase in the melting temperature was observed when the modified $\beta$-anomer was inserted into the middle of the TWJ region. We observed a positional effect of the TWJ when there was a neighbouring $\alpha-\mathrm{T}$ to the parallel-stranded 5-methyl- $N^{4}-(4-$ phenoxyphenyl)- $\alpha$-cytidine (Table 4 ).

Table 4. Thermal melting data $T_{\mathrm{m}} /{ }^{\circ} \mathrm{C}\left(\Delta T_{\mathrm{m}} /{ }^{\circ} \mathrm{C}\right)$ of Table 1 type TWJs and duplexes when using chimeric ODNs. $\mathbf{Z}$ is the modified nucleoside $\mathbf{1 8}$ and $T$ is $\alpha$-thymidine 20 .

\begin{tabular}{|c|c|c|c|c|}
\hline Entry & Sequence & $\begin{array}{l}\text { Inserted } \\
\text { base }\end{array}$ & $\begin{array}{l}\text { TWJ } \\
T_{\mathrm{m}}\left(\Delta T_{\mathrm{m}}\right) /{ }^{\circ} \mathrm{C}\end{array}$ & $\begin{array}{l}\text { Duplex } \\
T_{\mathrm{m}}\left(\Delta T_{\mathrm{m}}\right) /{ }^{\circ} \mathrm{C}\end{array}$ \\
\hline 10 & 5'-ТTTTTTСтTСТСТTTCC-3' & - & $27.6-$ & 47.8 \\
\hline 11 & 5'-ТTTTTTССТСТСТСТTTCC-3' & $\mathrm{C}$ & $30.0 \quad(2.4)$ & $38.0(-9.8)$ \\
\hline 12 & 5'-TTTTTTCT-3'-3'-Z-5'-5'-ТCTCTTTCC-3' & $\mathbf{Z}$ & $41.2(13.6)$ & $46.6(-1.2)$ \\
\hline 13 & 5'-TTTTTTC-3'-3'-TZ-5'-5'-TCTCTTTCC-3' & TZ & $39.2(11.6)$ & $44.4(-3.4)$ \\
\hline 14 & 5'-TTTTTTTCT-3'-3'-ZT-5'-5'-CTCTTTCC-3' & ZT & $46.4(18.8)$ & $45.4(-2.4)$ \\
\hline 15 & 5'-TTTTTTC-3'-3'-TZT-5'-5'-CTCTTTCC-3' & TZT & $42.8(15.2)$ & $42.8(-5.0)$ \\
\hline
\end{tabular}


On the other hand, an extra $\beta$-cytidine, forming a bulge in the same region of the corresponding duplex (entry 11), was found to destabilize the corresponding duplex $\left(\Delta T_{\mathrm{m}}=-9.8^{\circ} \mathrm{C}\right)$ and this is in good agreement with previously reported results. ${ }^{27}$ Again, on insertion of the intercalating $N^{4}$-phenoxyphenyl-5-methyl- $\alpha$-cytidine into the $24 \mathrm{mer}$ duplex the destabilization was reduced for the chimeric $\alpha, \beta$ ODNs in entries $12-14\left(\Delta T_{\mathrm{m}}=-1.2\right.$ to $-3.4^{\circ} \mathrm{C}$ ) when compared with the wild-type bulged ODN in entry $11\left(\Delta T_{\mathrm{m}}=-9.8^{\circ} \mathrm{C}\right)$. It is a reasonable supposition that a bulged duplex can be stabilized by the conjugated phenoxyphenyl intercalator, compared with a bulged $\mathrm{C}$.

\section{Discussion}

For neither duplexes nor triplexes was any appreciable stabilization observed when $N^{4}$-arylcytidines were inserted as intercalators in the middle of a targeting ODN. Whereas insertion of $N^{4}$-aryl substituted $\alpha$ nucleosides or their chimeric counterparts caused only a diminished decrease in the melting temperatures of the duplexes, the corresponding $\beta$ nucleosides showed a considerable decrease in the melting temperatures. When the intercalating moiety was inserted into the middle of an ODN its stabilizing effect seemed to depend on the way it was tethered, and recent reports vary from large stabilization $^{28}$ to large destabilization ${ }^{29,30}$ of the corresponding duplexes.

When the intercalating moiety is tethered at the end of the duplex, these reports ${ }^{28-30}$ agree on substantial stabilization. Kool and coworkers ${ }^{31}$ have also replaced thymine by pyrene as the base of a dangling nucleotide in a self-complementary duplex and observed a rise of $16^{\circ} \mathrm{C}$ in $T_{\mathrm{m}}$ due to the better stacking ability of the pyrene. This was ascribed to the lid effect of a stacking lipophilic moiety, which was assumed completely to cover the ends of the duplex.

As shown in Fig. 2 the same type of lid effect can explain the large stabilization of the TWJ observed in this work. NMR studies have shown that the presence

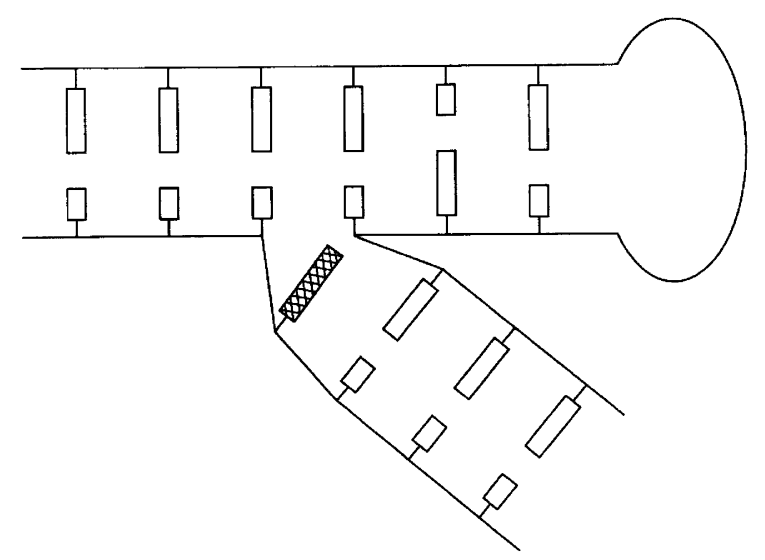

Fig. 2. Stabilizing a three-way junction by placing a bulged intercalating nucleoside on the top of the inclined arm. of unpaired bases in one strand at the branch point of a TWJ mediates stacking of two helical arms while the third is unstacked and is inclined to the two stacked helical arms. ${ }^{15,32-35}$ It is now assumed that the extra TWJ stability is achieved by placing the large non-polar $N^{4}$-aryl substituents of the nucleosides $6(\mathrm{X}), \mathbf{1 2}(\mathrm{Y})$ or $18(Z)$ on the top of the inclined arm. Considerable stabilization of the TWJ was also observed in all cases when the intercalating moiety was inserted at the adjacent sites of the TWJ. In these cases the lid effect due to coverage of the top of the inclined helical arm is also possible if one allows rupture of one $\mathrm{A}-\mathrm{T}$ base pair at the branch point. Including the modified nucleoside, there will in this case be two bulged nucleosides in one strand and one bulged nucleoside (A) in the other strand. This should still allow formation of TWJ. It has previously been shown that insertion of conjugated moiety further away from the branch point did not result in any stabilization of the $\mathrm{TWJ}^{20}$ reflecting that this will cause even further bulging at the branch point.

When compared with previous studies ${ }^{20-22}$ it is found that inserted 2-fluorenyl and 4-phenoxyphenyl $N^{4}$-substituted cytidines have a stabilizing effect on TWJs which is comparable to that of $N^{4}$-pyrenylmethylcytidine, whereas $N^{4}$-substitution with 2-benzylphenyl and 2-anilinophenyl accomplished more moderate stabilizations of TWJs.

\section{Experimental}

NMR spectra were recorded at $300 \mathrm{MHz}$ for ${ }^{1} \mathrm{H}$ NMR, 75.5 MHz for ${ }^{13} \mathrm{C}$ NMR and $121.5 \mathrm{MHz}$ for ${ }^{31} \mathrm{P}$ NMR on a Varian Gemini $2000300 \mathrm{MHz}$ spectrometer; $\delta$-values are in ppm relative to tetramethylsilane as internal standard $\left({ }^{1} \mathrm{H}\right.$ and ${ }^{13} \mathrm{C}$ ), and relative to $85 \%$ $\mathrm{H}_{3} \mathrm{PO}_{4}$ as external standard $\left({ }^{31} \mathrm{P}\right)$. Positive FAB mass spectra were recorded on a Kratos MS 50 RF spectrometer. Analytical silica gel TLC was performed on Merck precoated $60 \mathrm{~F}_{254}$ plates. The silica gel $(0.040-0.063 \mathrm{~mm})$ used for column chromatography was purchased from Merck.

The hybridization properties of the modified ODNs were studied with their complementary ODNs. DNA TWJ and DNA duplexes were studied in a salt buffer medium, $1 \mathrm{mmol}$ EDTA, $10 \mathrm{mmol} \quad \mathrm{Na}_{2} \mathrm{HPO}_{4}$ and $140 \mathrm{mmol} \mathrm{NaCl}$ at $\mathrm{pH} 7.0$, using equimolar amounts $(3 \mu \mathrm{M})$ from each strand. Before each experiment, all samples were heated to $90^{\circ} \mathrm{C}$ in a water bath for $5 \mathrm{~min}$ and then cooled slowly to $0^{\circ} \mathrm{C}$. The increase in the UV absorbance at $260 \mathrm{~nm}$ as a function of time was recorded while the temperature was raised gradually $\left(1^{\circ} \mathrm{C} \min ^{-1}\right)$ from 15 to $70^{\circ} \mathrm{C}$. The triplexes were formed from equimolar amounts $(3 \mu \mathrm{M})$ of each strand in slightly acidic salt buffer $10 \mathrm{mM}$ Na-acetate and $0.5 \mathrm{M} \mathrm{NaCl}$ at pH 5.5, 6.0 and 6.5 , and in the buffer $1 \mathrm{mM} \mathrm{Na} \mathrm{PO}_{4}, 0.05 \mathrm{mM}$ EDTA, $1 \mathrm{mM} \mathrm{MgCl}_{2}$ and $10 \mathrm{mM} \mathrm{NaCl}$ at $\mathrm{pH}$ 6.3.

Melting experiments were carried out on a PerkinElmer UV-VIS spectrometer Lamda 2 fitted with a PTP- 
6 Peltier temperature programming element measuring the absorbance at $260 \mathrm{~nm}$ in a $1-\mathrm{cm}$ cuvette. DNA syntheses were performed on a Pharmacia Gene Assembler Special ${ }^{\circledR}$ DNA-synthesizer. Desalting of oligonucleotides was accomplished using disposable NAP-10 columns (Pharmacia).

1-/3-O-Acetyl-2-deoxy-5-O-(4,4'-dimethoxytrityl $)$ - $\beta$-Dpentofuranosyl]-5-methyl-4-(2,4,6-trimethylbenzenesulfonyloxy) pyrimidin-2(IH)-one (2). A solution of 2,4,6trimethylbenzenesulfonyl chloride $(3.63 \mathrm{~g}, 16.6 \mathrm{mmol})$ in dry $\mathrm{CH}_{2} \mathrm{Cl}_{2}\left(10 \mathrm{ml}\right.$, freshly distilled from $\left.\mathrm{CaH}_{2}\right)$ was added to a vigorously stirred mixture of 1 (4.86 g, $8.3 \mathrm{mmol})$. Freshly distilled $\mathrm{Et}_{3} \mathrm{~N}(3.2 \mathrm{~g}, 32 \mathrm{mmol})$, and 4-dimethylaminopyridine $(0.1 \mathrm{~g})$ in dry $\mathrm{CH}_{2} \mathrm{Cl}_{2}(30 \mathrm{ml})$ was added at room temperature. The stirring was continued for $20 \mathrm{~h}$ and the resulting mixture was concentrated in vacuo at $30^{\circ} \mathrm{C}$ to $10 \mathrm{ml}$ and the resulting solution was purified by chromatography on a silica gel column eluted with $\mathrm{CH}_{2} \mathrm{Cl}_{2}$ to afford $2(5.48 \mathrm{~g}, 86 \%)$. ${ }^{1} \mathrm{H} \mathrm{NMR}\left(\mathrm{CDCl}_{3}\right): \delta 1.59\left(\mathrm{~s}, 3 \mathrm{H}, \mathrm{CH}_{3}\right), 2.04(\mathrm{~s}, 3 \mathrm{H}$, $\mathrm{CH}_{3}$ mesityl), 2.29 (s, 3 H, Ac), 2.33 (m, $\left.2 \mathrm{H}, 2^{\prime}-\mathrm{H}\right)$, 2.74 (s, $6 \mathrm{H}, 2 \times \mathrm{CH}_{3}$ mesityl) 3.45 (m. $2 \mathrm{H}, 5^{\prime}-\mathrm{H}$ ), 3.78 (s, $\left.6 \mathrm{H}, 2 \times \mathrm{OCH}_{3}\right), 4.19\left(\mathrm{~d}, 1 \mathrm{H}, J=2.4 \mathrm{~Hz}, 4^{\prime}-\mathrm{H}\right), 5.37$ (dd, $1 \mathrm{H}, J=2.4,4.8 \mathrm{~Hz}, 3^{\prime}-\mathrm{H}$ ), 6.22 (dd, $1 \mathrm{H}, J=5.8$, $\left.7.6 \mathrm{~Hz}, 1^{\prime}-\mathrm{H}\right), 6.84(\mathrm{~d}, 4 \mathrm{H}, J=8.8 \mathrm{~Hz}$, arom), 6.98 (s, $2 \mathrm{H}$, arom), 7.11-7.63 (m, $9 \mathrm{H}$, arom), 8.04 (s, $1 \mathrm{H}, 6-\mathrm{H})$. ${ }^{13} \mathrm{C} \mathrm{NMR}\left(\mathrm{CDCl}_{3}\right): \delta 11.97\left(\mathrm{CH}_{3}\right), 21.21\left(\mathrm{CH}_{3}\right), 21.44$ (Ac), $23.04\left(2 \times \mathrm{CH}_{3}\right), 39.67\left(\mathrm{C}-2^{\prime}\right), 55.57(2 \times \mathrm{OMe})$, $63.60\left({\left.\mathrm{C}-5^{\prime}\right),}^{\prime} 75.00\left(\mathrm{C}-3^{\prime}\right), 84.96\left(\mathrm{C}-1^{\prime}\right), 87.24\left(\mathrm{C}-4^{\prime}\right)\right.$, 87.49 (trityl), 104.41 (C-5), 113.67, 127.53, 128.35, $130.29,130.34,130.46,132.12,135.52,141.02,143.42$, $144.43,144.50,159.13$ (arom), 135.48 (C-6), 153.87 (C-2), $166.53(\mathrm{C}-4), 170.59\left(\mathrm{COCH}_{3}\right) . \mathrm{FAB} \mathrm{MS}\left(\mathrm{CHCl}_{3}+3-\right.$ nitrobenzyl alcohol ): $m / z 769\left(M+\mathrm{H}^{+}\right)$.

Preparation of $\mathbf{3}$ (general procedure). Compound $\mathbf{2}$ $(1.56 \mathrm{~g}, 2.03 \mathrm{mmol})$ was allowed to react with the appropriate aromatic amine $(3.9 \mathrm{mmol})$ in dry THF $(20 \mathrm{ml})$. $N, N$-Diisopropylethylamine $(0.6 \mathrm{ml})$ was added and the reaction mixture was refluxed for $36 \mathrm{~h}$. The solvent was removed in vacuo and the resulting gum was purified by chromatography on a silica gel column to give $\mathbf{3}$.

$3^{\prime}$ - O - Acetyl-2' - deoxy-5' - O - (4,4' - dimethoxytrityl) - 5 methyl- $\mathrm{N}^{4}-($ fluoren-2-yl) cytidine (3a). Yield $1.06 \mathrm{~g}$ $(70 \%) .{ }^{1} \mathrm{H}$ NMR $\left(\mathrm{CDCl}_{3}\right): \delta 1.62\left(\mathrm{~s}, 3 \mathrm{H}, \mathrm{CH}_{3}\right), 2.04(\mathrm{~s}$, $3 \mathrm{H}, \mathrm{Ac}), 2.35\left(\mathrm{~m}, 1 \mathrm{H}, 2^{\prime}-\mathrm{H}\right), 2.61\left(\mathrm{~m}, 1 \mathrm{H}, 2^{\prime}-\mathrm{H}\right), 3.48$ $\left(\mathrm{m}, 2 \mathrm{H}, 5^{\prime}-\mathrm{H}\right), 3.76(\mathrm{~s}, 6 \mathrm{H}, 2 \times \mathrm{OMe}), 3.85(\mathrm{~s}, 2 \mathrm{H}$, $\left.\mathrm{CH}_{2}\right), 4.16\left(\mathrm{~m}, 1 \mathrm{H}, 4^{\prime}-\mathrm{H}\right), 5.41\left(\mathrm{~m}, 1 \mathrm{H}, 3^{\prime}-\mathrm{H}\right), 6.51(\mathrm{~m}$, $\left.1 \mathrm{H}, 1^{\prime}-\mathrm{H}\right), 6.84(\mathrm{~d}, 4 \mathrm{H}, J=8.7 \mathrm{~Hz}$, arom $), 7.21-7.69$ (m, $16 \mathrm{H}$, arom), 7.77 (s, 1 H, NH), 8.14 (s, 1 H, 6- H). ${ }^{13} \mathrm{C} \mathrm{NMR}\left(\mathrm{CDCl}_{3}\right): \delta 12.63\left(\mathrm{CH}_{3}\right), 20.80(\mathrm{Ac}), 36.92$ $\left(\mathrm{CH}_{2}\right), 38.83\left(\mathrm{C}-2^{\prime}\right), 55.06\left(2 \times \mathrm{OMe}^{\prime}\right), 63.51\left(\mathrm{C}-5^{\prime}\right), 75.15$ $\left(\mathrm{C}-3^{\prime}\right), 83.81$ (C-1'), $85.71\left(\mathrm{C}-4^{\prime}\right), 86.84$ (trityl), 102.49 (C-5), 113.13-129.93 (arom), 135.28 (C-6), 136.28144.19 (arom), 155.90 (C-2), 158.56 (trityl), 161.14 (C-4),
170.28 $\left(\mathrm{COCH}_{3}\right)$. FAB MS $\left(\mathrm{CHCl}_{3}+3\right.$-nitrobenzyl alcohol $): m / z 750\left(M+\mathrm{H}^{+}\right)$.

3'- O - Acetyl - 2' - deoxy - 5' - O - (4,4' - dimethoxytrityl ) - 5 -

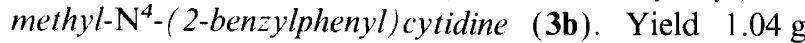
$(68 \%) .{ }^{1} \mathrm{H}$ NMR $\left(\mathrm{CDCl}_{3}\right): \delta 1.40\left(\mathrm{~s}, 3 \mathrm{H}, \mathrm{CH}_{3}\right), 2.08(\mathrm{~s}$, $3 \mathrm{H}, \mathrm{Ac}), 2.34\left(\mathrm{~m}, 1 \mathrm{H}, 2^{\prime}-\mathrm{H}\right), 2.60\left(\mathrm{~m}, 1 \mathrm{H}, 2^{\prime}-\mathrm{H}\right), 3.49$ $\left(\mathrm{m}, 2 \mathrm{H}, 5^{\prime}-\mathrm{H}\right), 3.79(\mathrm{~s}, 6 \mathrm{H}, 2 \times \mathrm{OMe}), 3.80(\mathrm{~s}, 2 \mathrm{H}$, $\left.\mathrm{CH}_{2}\right), 4.14\left(\mathrm{~m}, 1 \mathrm{H}, 4^{\prime}-\mathrm{H}\right), 5.44\left(\mathrm{~m}, 1 \mathrm{H}, 3^{\prime}-\mathrm{H}\right), 6.46(\mathrm{~m}$, $\left.1 \mathrm{H}, 1^{\prime}-\mathrm{H}\right), 6.68-7.69(\mathrm{~m}, 22 \mathrm{H}$, arom $), 8.04,8.07(2 \times \mathrm{s}$, $2 \mathrm{H}, \mathrm{NH}, 6-\mathrm{H}) .{ }^{13} \mathrm{C} \mathrm{NMR}\left(\mathrm{CDCl}_{3}\right): \delta 11.89\left(\mathrm{CH}_{3}\right)$, 20.91 ( Ac), $37.87\left(\mathrm{CH}_{2}\right), 38.71\left(\mathrm{C}-2^{\prime}\right), 55.16(2 \times \mathrm{OMe})$, $63.61\left(\mathrm{C}-5^{\prime}\right), 75.33\left(\mathrm{C}-3^{\prime}\right), 83.86\left(\mathrm{C}^{\prime} \mathbf{1}^{\prime}\right), 85.73\left(\mathrm{C}-4^{\prime}\right)$, 86.96 (trityl), 102.55 (C-5), 113.33-135.46 (arom), 135.52 (C-6), 136.09-150.61 (arom), 155.86 (C-2), 158.83 (trityl), $161.74(\mathrm{C}-4), 170.66\left(\mathrm{COCH}_{3}\right)$.

3'- O - Acetyl-2' - deoxy - 5' - O - (4,4' - dimethoxytrityl) -5 methyl- $\mathrm{N}^{4}-(2-$ phenylaminophenyl)cytidine (3c). Yield $1.02 \mathrm{~g}(67 \%) .{ }^{1} \mathrm{H}$ NMR $\left(\mathrm{CDCl}_{3}\right): \delta 1.32\left(\mathrm{~s}, 3 \mathrm{H}, \mathrm{CH}_{3}\right)$, $2.06(\mathrm{~s}, 3 \mathrm{H}, \mathrm{Ac}), 2.34\left(\mathrm{~m}, 1 \mathrm{H}, 2^{\prime}-\mathrm{H}\right), 2.61(\mathrm{~m}, 1 \mathrm{H}$, $\left.2^{\prime}-\mathrm{H}\right), 3.48\left(\mathrm{~m}, 2 \mathrm{H}, 5^{\prime}-\mathrm{H}\right), 3.77$ (s, $\left.6 \mathrm{H}, 2 \times \mathrm{OMe}\right), 4.16$ (m. 1 H, 4'-H), 5.40 (m. 1 H. 3'-H). 6.51 (m, 1 H. 1'-H). 6.76-7.45 (m, $22 \mathrm{H}$, arom), $7.70(\mathrm{~s}, 1 \mathrm{H}, 6-\mathrm{H}), 8.31,8.34$ $(2 \times \mathrm{s}, 2 \mathrm{H}, 2 \times \mathrm{NH}) .{ }^{13} \mathrm{C} \mathrm{NMR}\left(\mathrm{CDCl}_{3}\right): \delta 12.09\left(\mathrm{CH}_{3}\right)$, 20.91 (Ac), 38.87 (C-2'), 55.15 (2× OMe), 63.65 (C-5'), $75.43\left(\mathrm{C}-3^{\prime}\right), 83.92\left(\mathrm{C}-1^{\prime}\right), 85.76\left(\mathrm{C}-4^{\prime}\right), 86.99$ (trityl), 103.14 (C-5), 113.14-134.08 (arom), 135.45 (C-6), 135.48-144.74 (arom), 155.83 (C-2), 158.82 (trityl), $161.42(\mathrm{C}-4), 170.66\left(\mathrm{COCH}_{3}\right)$.

$2^{\prime}$ - Deoxy - 5' - O - (4,4' - dimethoxytrityl) - 5 - methyl - $\mathrm{N}^{4}$ (fluoren-2-yl) cytidine (4a). A solution of satd. $\mathrm{NH}_{3}$ in $\mathrm{MeOH}(30 \mathrm{ml})$ was added to a stirred solution of 3a $(1 \mathrm{~g}, 1.34 \mathrm{mmol})$ in $\mathrm{MeOH}(30 \mathrm{ml})$ at $0^{\circ} \mathrm{C}$. The mixture was stirred for $4 \mathrm{~h}$ at $0^{\circ} \mathrm{C}$ and then overnight at room temperature. The solvent was removed in vacuo and the resulting gum was chromatographed on a silica gel column $\left(\mathrm{MeOH}-\mathrm{CHCl}_{3}, 0-2 \%, \mathrm{v} / \mathrm{v}\right)$ to give $4 a(934 \mathrm{mg}$, $99 \%)$ as a yellow foam. ${ }^{1} \mathrm{H}$ NMR $\left(\mathrm{CDCl}_{3}\right): \delta 1.59(\mathrm{~s}$, $\left.3 \mathrm{H}, \mathrm{CH}_{3}\right), 2.29\left(\mathrm{~m}, 1 \mathrm{H}, 2^{\prime}-\mathrm{H}\right), 2.49\left(\mathrm{~m}, 1 \mathrm{H}, 2-\mathrm{H}^{\prime}\right), 3.43$ $\left(\mathrm{m}, 2 \mathrm{H}, 5^{\prime}-\mathrm{H}\right), 3.73(\mathrm{~s}, 6 \mathrm{H}, 2 \times \mathrm{OMe}), 3.79(\mathrm{~m}, 1 \mathrm{H}$, $\left.3^{\prime}-\mathrm{H}\right), 3.81\left(\mathrm{~s}, 2 \mathrm{H}, \mathrm{CH}_{2}\right), 4.10\left(\mathrm{~m}, 1 \mathrm{H}, 4^{\prime}-\mathrm{H}\right), 4.53(\mathrm{~s}$, $1 \mathrm{H}, \mathrm{OH}), 6.41\left(\mathrm{~m}, 1 \mathrm{H}, 1^{\prime}-\mathrm{H}\right), 6.78(\mathrm{~d}, 4 \mathrm{H}, J=8.4 \mathrm{~Hz}$, arom), 7.19-7.78 (m, $17 \mathrm{H}, \mathrm{NH}$, arom $), 8.08(\mathrm{~s}, 1 \mathrm{H}$, 6-H ). ${ }^{13} \mathrm{C} \mathrm{NMR}\left(\mathrm{CDCl}_{3}\right): \delta 12.64\left(\mathrm{CH}_{3}\right), 36.98\left(\mathrm{CH}_{2}\right)$, $42.02\left(\mathrm{C}-2^{\prime}\right), 55.12(2 \times \mathrm{OMe}), 63.37\left(\mathrm{C}-5^{\prime}\right), 71.86\left(\mathrm{C}-3^{\prime}\right)$, $85.98,86.18\left(\mathrm{C}-1^{\prime}, \mathrm{C}-4^{\prime}\right), 86.62$ (trityl), 102.10 (C-5), 113.06-129.99 (arom), 135.49 (C-6), 135.52-144.38 (arom), 155.78 (C-2), 158.53 (trityl), 161.12 (C-4). FAB $\mathrm{MS}\left(\mathrm{CHCl}_{3}+3\right.$-nitrobenzyl alcohol $): m / z 708\left(M+\mathrm{H}^{+}\right)$.

Preparation of $\mathbf{4 b , c}$ (general procedure). To a stirred solution of $\mathbf{3 b}, \mathbf{c}(1.5 \mathrm{mmol})$ in $\mathrm{MeOH}(30 \mathrm{ml})$ was added $\mathrm{MeONa}(810 \mathrm{mg}, 15 \mathrm{mmol})$ in $\mathrm{MeOH}(10 \mathrm{ml})$ at room temperature and the mixture was stirred for $1 \mathrm{~h} . \mathrm{NH}_{4} \mathrm{Cl}$ ( $802 \mathrm{mg}, 15 \mathrm{mmol}$ ) was added and the reaction mixture was stirred for $30 \mathrm{~min}$. The solvent was removed in vacuo, 
and the residue was chromatographed on a silica gel column ( $\left.\mathrm{MeOH}-\mathrm{CH}_{2} \mathrm{Cl}_{2}, 0-2 \%, \mathrm{v} / \mathrm{v}\right)$ affording $\mathbf{4 b}, \mathbf{c}$ in $100 \%$ yield.

$2^{\prime}$-Deoxy-5'-O- (4,4'-dimethoxytrityl) -5-methyl- $\mathrm{N}^{4}-(2-$ benzylphenyl) cytidine (4b). ${ }^{1} \mathrm{H}$ NMR $\left(\mathrm{CDCl}_{3}\right): \delta 1.58(\mathrm{~s}$, $\left.3 \mathrm{H}, \mathrm{CH}_{3}\right), 2.14\left(\mathrm{~m}, 1 \mathrm{H}, 2^{\prime}-\mathrm{H}\right), 2.48\left(\mathrm{~m}, 1 \mathrm{H}, 2-\mathrm{H}^{\prime}\right), 3.19$ $\left(\mathrm{m}, 2 \mathrm{H}, 5^{\prime}-\mathrm{H}\right), 3.72(\mathrm{~s}, 6 \mathrm{H}, 2 \times \mathrm{OMe}), 3.75(\mathrm{~m}, 1 \mathrm{H}$, $\left.3^{\prime}-\mathrm{H}\right), 3.88\left(\mathrm{~s}, 2 \mathrm{H}, \mathrm{CH}_{2}\right), 4.28\left(\mathrm{~m}, 1 \mathrm{H}, 4^{\prime}-\mathrm{H}\right), 5.26$ (s, $1 \mathrm{H}, \mathrm{OH}), 6.18\left(\mathrm{~m}, 1 \mathrm{H}, 1^{\prime}-\mathrm{H}\right), 6.84-7.56(\mathrm{~m}, 23 \mathrm{H}, \mathrm{NH}$, arom), $8.43(\mathrm{~s}, 1 \mathrm{H}, 6-\mathrm{H}) .{ }^{13} \mathrm{C} \mathrm{NMR}\left(\mathrm{CDCl}_{3}\right): \delta 12.84$ $\left(\mathrm{CH}_{3}\right), 38.50\left(\mathrm{CH}_{2}\right), 40.47\left(\mathrm{C}-2^{\prime}\right), 55.10(2 \times \mathrm{OMe}), 63.67$ $\left(\mathrm{C}-5^{\prime}\right), 70.50\left(\mathrm{C}-3^{\prime}\right), 85.88,86.20\left(\mathrm{C}-1^{\prime}, \mathrm{C}-4^{\prime}\right), 86.43$ (trityl), 102.00 (C-5), 113.14-135.64 (arom), 136.73 (C-6), 138.21-150.52 (arom), 154.78 (C-2), 158.35 (trityl), 162.59 (C-4).

$2^{\prime}$ - Deoxy-5'-O- (4,4'-dimethoxytrityl) -5-methyl- $\mathrm{N}^{4}-(2-$ phenylaminophenyl)cytidine $(4 \mathrm{c}) .{ }^{1} \mathrm{H} \mathrm{NMR}\left(\mathrm{CDCl}_{3}\right): \delta$ $1.60\left(\mathrm{~s}, 3 \mathrm{H}, \mathrm{CH}_{3}\right), 2.22\left(\mathrm{~m}, 1 \mathrm{H}, 2^{\prime}-\mathrm{H}\right), 2.51(\mathrm{~m}, 1 \mathrm{H}$, $\left.2^{\prime}-\mathrm{H}\right), 3.27\left(\mathrm{~m}, 2 \mathrm{H}, 5^{\prime}-\mathrm{H}\right), 3.75$ (s, $\left.6 \mathrm{H}, 2 \times \mathrm{OMe}\right), 3.96$ $\left(\mathrm{m}, 1 \mathrm{H}, 3^{\prime}-\mathrm{H}\right), 4.34\left(\mathrm{~m}, 1 \mathrm{H}, 4^{\prime}-\mathrm{H}\right), 5.36(\mathrm{~s}, 1 \mathrm{H}, \mathrm{OH})$, $6.29\left(\mathrm{~m}, 1 \mathrm{H}, 1^{\prime}-\mathrm{H}\right), 6.79-7.68(\mathrm{~m}, 24 \mathrm{H}, 2 \times \mathrm{NH}$, arom), $8.26(\mathrm{~s}, 1 \mathrm{H}, 6-\mathrm{H}) \cdot{ }^{13} \mathrm{C} \mathrm{NMR}\left(\mathrm{CDCl}_{3}\right): \delta 12.65\left(\mathrm{CH}_{3}\right)$, $40.56\left(\mathrm{C}-2^{\prime}\right), 54.97(2 \times \mathrm{OMe}), 63.64\left(\mathrm{C}-5^{\prime}\right), 70.50\left(\mathrm{C}-3^{\prime}\right)$, 85.46, $85.57\left(\mathrm{C}-1^{\prime}, \mathrm{C}-4^{\prime}\right), 85.93$ (trityl), 102.67 (C-5), 113.35-135.63 (arom), 135.65 (C-6), 137.65-144.00 (arom), 154.76 (C-2), 158.35 (trityl), 162.08 (C-4).

Phosphoramidite 5. Compound $4(0.85 \mathrm{mmol})$ was coevaporated with dry $\mathrm{MeCN}$ and dissolved in a mixture of $\mathrm{N}, \mathrm{N}$-diisopropylethylamine $(0.8 \mathrm{ml})$ and dry $\mathrm{CH}_{2} \mathrm{Cl}_{2}$ $(2.5 \mathrm{ml})$. 2-Cyanoethyl $N, N$-diisopropylchlorophosphoramidite $(0.35 \mathrm{ml}, 1.53 \mathrm{mmol})$ was added dropwise under an $\mathrm{Ar}$ atmosphere. The reaction mixture was stirred at room temperature ( $1 \mathrm{~h}$ for $\mathbf{4 a}, 1.5 \mathrm{~h}$ for $\mathbf{4 b}$, and $2 \mathrm{~h}$ for $4 \mathrm{c})$. The reaction mixture was quenched by addition of $\mathrm{MeOH}(2 \mathrm{ml})$. EtOAc and $\mathrm{CH}_{2} \mathrm{Cl}_{2}(100 \mathrm{ml})$ were added to the reaction mixture which was then washed with $\mathrm{NaHCO}_{3}(3 \times 30 \mathrm{ml})$. The organic layer was dried over $\mathrm{Na}_{2} \mathrm{SO}_{4}$, and evaporated in vacuo. The product was purified on a silica gel column (EtOAc$\mathrm{CH}_{2} \mathrm{Cl}_{2}-\mathrm{Et}_{3} \mathrm{~N}, 15: 80: 5, \mathrm{v} / \mathrm{v}$ ). The resulting gum was dissolved in $5 \mathrm{ml}$ of dry toluene and the solution was added dropwise to cold petroleum ether (b.p. $60-80^{\circ} \mathrm{C}$ ) $(200 \mathrm{ml})$ with stirring. The solid product was filtered off to give a white compound. The yield was $88 \%, 85 \%$ and $83 \%$ for $\mathbf{5 a}, \mathbf{5 b}$ and $\mathbf{5 c}$, respectively. ${ }^{31} \mathrm{P}$ NMR $\left(\mathrm{CDCl}_{3}\right)$ : $\delta 147.96$ and $148.64 ; 147.89$ and $148.52 ; 147.99$ and 148.54, respectively. FAB MS $\left(\mathrm{CHCl}_{3}+3\right.$-nitrobenzyl alcohol $): m / z 910\left(M+\mathrm{H}^{+}\right)$and $911\left(M+\mathrm{H}^{+}\right)$for $\mathbf{5 b}$ and $5 \mathbf{c}$, respectively.

1-[3-O-Acetyl-2-deoxy-5-O-(4,4'-dimethoxytrityl)- $\alpha$-Dpentofuranosyl]-5-methyl-4-(2,4,6-trimethylbenzenesulfonyloxy) pyrimidin-2 $(1 \mathrm{H})$-one $(\mathbf{8})$. Using the same procedure as for the synthesis of $\mathbf{2}$, compound $\mathbf{7}^{22}$ afforded $8(2.1 \mathrm{~g}, 80 \%) .{ }^{1} \mathrm{H}$ NMR $\left(\mathrm{CDCl}_{3}\right): \delta 1.90\left(\mathrm{~s}, 3 \mathrm{H}, \mathrm{CH}_{3}\right)$, $2.09\left(\mathrm{~s}, 3 \mathrm{H}, \mathrm{CH}_{3}\right), 2.30(\mathrm{~s}, 3 \mathrm{H}, \mathrm{Ac}), 2.74(\mathrm{~s}, 6 \mathrm{H}$, $\left.2 \times \mathrm{CH}_{3}\right) 2.78\left(\mathrm{~m}, 1 \mathrm{H}, 2^{\prime}-\mathrm{H}\right), 3.21\left(\mathrm{~m}, 1 \mathrm{H}, 2^{\prime}-\mathrm{H}\right), 3.47$ $\left(\mathrm{m}, 2 \mathrm{H}, 5^{\prime}-\mathrm{H}\right), 3.78\left(\mathrm{~s}, 6 \mathrm{H}, 2 \times \mathrm{OCH}_{3}\right), 4.52(\mathrm{~m}, 1 \mathrm{H}$, $\left.4^{\prime}-\mathrm{H}\right), 5.23\left(\mathrm{~m}, 1 \mathrm{H}, 3^{\prime}-\mathrm{H}\right), 6.19\left(\mathrm{~m}, 1 \mathrm{H}, 1^{\prime}-\mathrm{H}\right), 6.82(\mathrm{~d}$, $4 \mathrm{H}, J=8.4 \mathrm{~Hz}$, arom), 7.00-77.40 (m, $11 \mathrm{H}$, arom), 7.70 (s, $1 \mathrm{H}, 6-\mathrm{H}) \cdot{ }^{13} \mathrm{C} \mathrm{NMR}\left(\mathrm{CDCl}_{3}\right): \delta 12.17\left(\mathrm{CH}_{3}\right), 20.71$ $\left(\mathrm{CH}_{3}\right), 21.00(\mathrm{Ac}), 22.59\left(2 \times \mathrm{CH}_{3}\right), 39.03\left(\mathrm{C}-2^{\prime}\right), 55.11$ $(2 \times \mathrm{OMe}), 63.82\left(\mathrm{C}-5^{\prime}\right), 75.11\left(\mathrm{C}-3^{\prime}\right), 86.75\left(\mathrm{C}-1^{\prime}\right), 87.19$ (C-4'), 89.20 (trityl), 102.84 (C-5), 113.00-135.40 (arom), 135.58 (C-6), 140.75-144.33 (arom), 153.30 (C-2), 158.69 (trityl), 166.60 (C-4), $169.71\left(\mathrm{COCH}_{3}\right)$. FAB MS $\left(\mathrm{CHCl}_{3}+3\right.$-nitrobenzyl alcohol $): m / z 769\left(M+\mathrm{H}^{+}\right)$.

1-[3-O-Acetyl-2-deoxy-5-O-( 4,4'-dimethoxytrityl)- $\alpha$-Dpentofuranosyl]-5-methyl-4-( fluoren-2-ylamino) pyrimidin$2(1 \mathrm{H})$-one $(9)$. Compound $8(1.56 \mathrm{~g}, 2.03 \mathrm{mmol})$ was allowed to react with 2-aminofluorene $(0.51 \mathrm{~g}, 2.8 \mathrm{mmol})$ in dry THF $(20 \mathrm{ml}) . \quad N, N$-Diisopropylethylamine $(0.6 \mathrm{ml})$ was added and the reaction mixture was refluxed for $36 \mathrm{~h}$. The solvent was removed in vacuo and the resulting gum was purified by chromatography with $\mathrm{CH}_{2} \mathrm{Cl}_{2}$ to give $9(1.1 \mathrm{~g}, 74 \%) .{ }^{1} \mathrm{H} \mathrm{NMR}\left(\mathrm{CDCl}_{3}\right): \delta$ $1.93\left(\mathrm{~s}, 3 \mathrm{H}, \mathrm{CH}_{3}\right), 2.13(\mathrm{~s}, 3 \mathrm{H}, \mathrm{Ac}), 2.32(\mathrm{~d}, 1 \mathrm{H}, J=$ $\left.15.2 \mathrm{~Hz}, 2^{\prime}-\mathrm{H}\right), 2.89\left(\mathrm{~m}, 1 \mathrm{H}, 2^{\prime}-\mathrm{H}\right), 3.22-3.31(\mathrm{~m}, 2 \mathrm{H}$, $\left.5^{\prime}-\mathrm{H}\right), 3.81(\mathrm{~s}, 6 \mathrm{H}, 2 \times \mathrm{OMe}), 3.90\left(\mathrm{~s}, 2 \mathrm{H}, \mathrm{CH}_{2}\right), 4.55$ $\left(\mathrm{m}, 1 \mathrm{H}, 4^{\prime}-\mathrm{H}\right), 5.30\left(\mathrm{~d}, 1 \mathrm{H}, J=6.7 \mathrm{~Hz}, 3^{\prime}-\mathrm{H}\right), 6.41(\mathrm{~d}$, $\left.1 \mathrm{H}, J=7.7 \mathrm{~Hz}, 1^{\prime}-\mathrm{H}\right), 6.85$ (d, $4 \mathrm{H}, J=8.7 \mathrm{~Hz}$, arom), $7.18-7.73\left(\mathrm{~m}, 17 \mathrm{H}, \mathrm{NH}\right.$, arom), $8.20(\mathrm{~s}, 1 \mathrm{H}, 6-\mathrm{H}) .{ }^{13} \mathrm{C}$ NMR $\left(\mathrm{CDCl}_{3}\right): \delta 13.44\left(\mathrm{CH}_{3}\right), 20.78(\mathrm{Ac}), 36.97\left(\mathrm{CH}_{2}\right)$, $39.80\left(\mathrm{C}-2^{\prime}\right), 55.13(2 \times \mathrm{OMe}), 63.85\left(\mathrm{C}-5^{\prime}\right), 75.21\left(\mathrm{C}-3^{\prime}\right)$, $86.58\left(\mathrm{C}-1^{\prime}\right), 86.61\left(\mathrm{C}-4^{\prime}\right), 88.29$ (trityl), 101.01 (C-5), 113.14-130.04 (arom), 135.57 (C-6), 135.28-144.47 (arom), 155.88 (C-2), 158.66 (trityl ), 161.50 (C-4), 169.86 $\left(\mathrm{COCH}_{3}\right)$. FAB MS $\left(\mathrm{CHCl}_{3}+3\right.$-nitrobenzyl alcohol $)$ : $m / z 750\left(M+\mathrm{H}^{+}\right)$.

1-[2-Deoxy-5-O-(4,4'-dimethoxytrityl)- $\alpha$-D-pentofuranosyl]-5-methyl-4-(fluoren-2-ylamino) pyrimidin-2(1H)one (10). A solution of $\mathrm{NaOMe}(0.48 \mathrm{~g}, 12 \mathrm{mmol})$ in $\mathrm{MeOH}(10 \mathrm{ml})$ was added to a stirred solution of 9 $(0.9 \mathrm{~g}, 1.2 \mathrm{mmol})$ in $\mathrm{MeOH}(20 \mathrm{ml})$ at $0{ }^{\circ} \mathrm{C}$, and stirred for $1 \mathrm{~h}$ at room temperature. $\mathrm{NH}_{4} \mathrm{Cl}(1.2 \mathrm{mmol})$ was added and the reaction mixture was stirred for $15 \mathrm{~min}$. The solvent was removed in vacuo and chromatographed on a silica gel column $\left(\mathrm{MeOH}-\mathrm{CHCl}_{3}, 0-2 \%, \mathrm{v} / \mathrm{v}\right)$ to give $10(830 \mathrm{mg}, 98 \%)$ as a yellow foam. ${ }^{1} \mathrm{H}$ NMR $\left(\mathrm{CDCl}_{3}\right): \delta 1.69\left(\mathrm{~s}, 3 \mathrm{H}, \mathrm{CH}_{3}\right), 2.61(\mathrm{~d}, 1 \mathrm{H}, J=14.5 \mathrm{~Hz}$, $\left.2^{\prime}-\mathrm{H}\right), 2.73\left(\mathrm{~m}, 1 \mathrm{H}, 2^{\prime}-\mathrm{H}\right), 3.14-3.27\left(\mathrm{~m}, 2 \mathrm{H}, 5^{\prime}-\mathrm{H}\right)$, 3.77 (s, $6 \mathrm{H}, 2 \times \mathrm{OMe}), 3.84\left(\mathrm{~s}, 2 \mathrm{H}, \mathrm{CH}_{2}\right), 3.85(\mathrm{~m}, 1 \mathrm{H}$, $\left.3^{\prime}-\mathrm{H}\right), 4.49$ (d, $\left.1 \mathrm{H}, J=5.0 \mathrm{~Hz}, 4^{\prime}-\mathrm{H}\right), 4.56$ (s, $\left.1 \mathrm{H}, \mathrm{OH}\right)$, $6.06\left(\mathrm{~d}, 1 \mathrm{H}, J=6.5 \mathrm{~Hz}, 1^{\prime}-\mathrm{H}\right), 6.84(\mathrm{~d}, 4 \mathrm{H}, J=8.7 \mathrm{~Hz}$, arom), 7.18-7.69 (m, $17 \mathrm{H}, \mathrm{NH}$, arom $), 8.08(\mathrm{~s}, 1 \mathrm{H}$, 6-H ). ${ }^{13} \mathrm{C} \mathrm{NMR}\left(\mathrm{CDCl}_{3}\right): \delta 12.92\left(\mathrm{CH}_{3}\right), 36.97\left(\mathrm{CH}_{2}\right)$, $41.35\left(\mathrm{C}-2^{\prime}\right), 55.10(2 \times \mathrm{OMe}), 64.34\left(\mathrm{C}-5^{\prime}\right), 72.66\left(\mathrm{C}-3^{\prime}\right)$, $86.29\left(\mathrm{C}-1^{\prime}\right), 89.25\left(\mathrm{C}-4^{\prime}\right), 90.94$ (trityl), 101.62 (C-5), 113.18-130.07 (arom), 135.84 (C-6), 135.93-144.77 (arom), 156.07 (C-2), 158.57 (trityl), 161.18 (C-4). FAB $\mathrm{MS}\left(\mathrm{CHCl}_{3}+3\right.$-nitrobenzyl alcohol $): m / z \quad 708\left(M+\mathrm{H}^{+}\right)$. 
Phosphoramidite 11. Using a reaction time of $4 \mathrm{~h}$ compound $\mathbf{1 1}$ was synthesized in a similar way to $\mathbf{5}$. The product was purified on a silica gel column (EtOAc- $\mathrm{CH}_{2} \mathrm{Cl}_{2}-\mathrm{Et}_{3} \mathrm{~N}$ petroleum ether $\left(60-80^{\circ} \mathrm{C}\right.$ ), $20: 50: 10: 20, \mathrm{v} / \mathrm{v})$. The resulting gum was dissolved in $5 \mathrm{ml}$ of dry toluene and the solution was added dropwise to cold petroleum ether $\left(60-80^{\circ} \mathrm{C}\right)(200 \mathrm{ml})$ with stirring. The solid product was filtered off to give a white compound in $84 \%$ yield. ${ }^{31} \mathrm{P}$ NMR $\left(\mathrm{CDCl}_{3}\right): \delta 150.48$, 150.85 .

1-[5-O-Acetyl-2-deoxy-3-O-(4,4'-dimethoxytrityl $)$ - $\alpha$-Dpentofuranosyl]-5-methyl-4-(2,4,6-trimethylbenzenesulfonyloxy) pyrimidin- $2(1 \mathrm{H})$-one (14). Using the same procedure as for the synthesis of $\mathbf{2}$, compound $\mathbf{1 3}$ afforded 14 as yellow foam $(2.0 \mathrm{~g}, 76 \%)$. ${ }^{1} \mathrm{H}$ NMR $\left(\mathrm{CDCl}_{3}\right): \delta$ $1.89\left(\mathrm{~s}, 3 \mathrm{H}, \mathrm{CH}_{3}\right), 1.98\left(\mathrm{~s}, 3 \mathrm{H}, \mathrm{CH}_{3}\right), 2.00(\mathrm{~s}, 3 \mathrm{H}, \mathrm{Ac})$, 2.37, (m, 1 H, 2'-H), $2.62\left(\mathrm{~m}, 1 \mathrm{H}, 2^{\prime}-\mathrm{H}\right), 2.99(\mathrm{~s}, 6 \mathrm{H}$, $\left.2 \times \mathrm{CH}_{3}\right), \quad 3.54-3.76\left(\mathrm{~m}, 2 \mathrm{H}, 5^{\prime}-\mathrm{H}\right), 3.79(\mathrm{~s}, 6 \mathrm{H}$, $\left.2 \times \mathrm{OCH}_{3}\right), 4.50\left(\mathrm{~m}, 1 \mathrm{H}, 4^{\prime}-\mathrm{H}\right), 5.26\left(\mathrm{~m}, 1 \mathrm{H}, 3^{\prime}-\mathrm{H}\right)$, $6.18\left(\mathrm{~m}, 1 \mathrm{H}, 1^{\prime}-\mathrm{H}\right), 6.82(\mathrm{~d}, 4 \mathrm{H}, J=8.0 \mathrm{~Hz}$, arom $)$, 7.21-7.43 (m, $11 \mathrm{H}$, arom), $7.64(\mathrm{~s}, 1 \mathrm{H}, 6-\mathrm{H}) .{ }^{13} \mathrm{C}$ NMR $\left(\mathrm{CDCl}_{3}\right): \delta 12.21\left(\mathrm{CH}_{3}\right), 20.54\left(\mathrm{CH}_{3}\right), 20.92(\mathrm{Ac}) .22 .50$

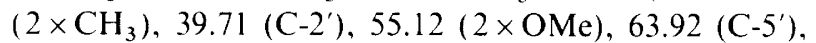
$74.23\left(\mathrm{C}-3^{\prime}\right), 86.23\left(\mathrm{C}-1^{\prime}\right), 88.01\left(\mathrm{C}-4^{\prime}\right), 89.23$ (trityl), 102.64 (C-5), 113.52-135.49 (arom), 135.59 (C-6), 140.58-144.48 (arom), 153.64 (C-2), 158.88 (trityl), $166.18(\mathrm{C}-4), 170.29\left(\mathrm{COCH}_{3}\right)$. FAB MS $\left(\mathrm{CHCl}_{3}+3-\right.$ nitrobenzyl alcohol ): $m / z 769\left(M+\mathrm{H}^{+}\right)$.

1-[5-O-Acetyl-2-deoxy-3-O-( 4,4'-dimethoxytrityl)- $\alpha$-Dpentofuranosyl] - 5 - methyl-4 - (4 - phenoxyphenylamino)pyrimidin-2(1H)-one (15). Compound 14 (1.56g, $2.03 \mathrm{mmol})$ was allowed to react with 4-phenoxyaniline $(0.9 \mathrm{mmol})$ in dry THF $(20 \mathrm{ml})$. $N, N$-Diisopropylethylamine $(0.6 \mathrm{ml})$ was added and the reaction mixture was refluxed for $36 \mathrm{~h}$. The solvent was removed in vacuo and the resulting gum was purified on a silica gel column $\left(\mathrm{MeOH}-\mathrm{CH}_{2} \mathrm{Cl}_{2}, 0-1 \%, \mathrm{v} / \mathrm{v}\right)$ to give 15 $(1.11 \mathrm{~g}, 73 \%)$.

1-[2-Deoxy-3-O-(4,4'-dimethoxytrityl)- $\alpha$-D-pentofuranosyl]-5-methyl-4-(4-phenoxyphenylamino) pyrimidin-2 (1H)-one (16). To a stirred solution of $15(1.13 \mathrm{~g}$, $1.5 \mathrm{mmol})$ in $\mathrm{MeOH}(20 \mathrm{ml})$ was added $\mathrm{NaOMe}$ $(810 \mathrm{mg}, 15 \mathrm{mmol})$ in $\mathrm{MeOH}(10 \mathrm{ml})$ at room temperature and the solution was stirred for $1 \mathrm{~h} . \mathrm{NH}_{4} \mathrm{Cl}$ $(802 \mathrm{mg}, 15 \mathrm{mmol}$ ) was added and the reaction mixture was stirred for $30 \mathrm{~min}$. The solvent was removed in vacuo, and the residue was chromatographed on a silica gel column ( $\left.\mathrm{MeOH}-\mathrm{CH}_{2} \mathrm{Cl}_{2}, 0-5 \%, \mathrm{v} / \mathrm{v}\right)$ affording 16 in $100 \%$ yield $(1.06 \mathrm{~g}) .{ }^{1} \mathrm{H}$ NMR $\left(\mathrm{CDCl}_{3}\right): \delta 1.91(\mathrm{~s}, 3 \mathrm{H}$, $\left.\mathrm{CH}_{3}\right), 2.17$ (m, $\left.1 \mathrm{H}, 2^{\prime}-\mathrm{H}\right), 2.89$ (m, $\left.1 \mathrm{H}, 2^{\prime}-\mathrm{H}\right), 3.11-3.29$ $\left(\mathrm{m}, 2 \mathrm{H}, 5^{\prime}-\mathrm{H}\right), 3.77(\mathrm{~s}, 6 \mathrm{H}, 2 \times \mathrm{OMe}), 3.79(\mathrm{~m}, 1 \mathrm{H}$, $\left.4^{\prime}-\mathrm{H}\right), 4.42\left(\mathrm{~d}, 1 \mathrm{H}, J=4.7 \mathrm{~Hz}, 3^{\prime}-\mathrm{H}\right), 6.24(\mathrm{~m}, 1 \mathrm{H}$, $\left.1^{\prime}-\mathrm{H}\right), 6.82-7.41(\mathrm{~m}, 22 \mathrm{H}, \mathrm{NH}$, arom $), 7.57(\mathrm{~s}, 1 \mathrm{H}$, 6-H ). ${ }^{13} \mathrm{C} \mathrm{NMR}\left(\mathrm{CDCl}_{3}\right): \delta 13.42\left(\mathrm{CH}_{3}\right), 40.75\left(\mathrm{C}-2^{\prime}\right)$,

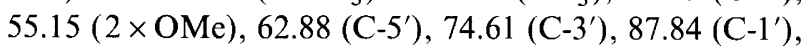

88.21 (C-4'), 89.90 (trityl), 100.85 (C-5), 113.43-133.50 (arom), 136.10 (C-6), 136.25-145.04 (arom), 156.11 (C-2), 158.79 (trityl), 161.59 (C-4).

Phosphoramidite 17. Compound 17 was synthesized in $83 \%$ yield in a similar way to $5 \mathbf{b}$. ${ }^{31} \mathrm{P} \mathrm{NMR}\left(\mathrm{CDCl}_{3}\right)$ : $\delta 150.05$ and 150.87. FAB MS $\left(\mathrm{CHCl}_{3}+3\right.$-nitrobenzyl alcohol ): $m / z 912\left(M+\mathrm{H}^{+}\right)$.

\section{References}

1. English, U. and Gauss, D. Angew. Chem., Int. Ed. Engl. 30 (1991) 613 .

2. Hélène, C. and Toulmé, J.-J. Biochem. Biophys. Acta 1049 (1990) 99.

3. Thuong, N. T. and Hélène, C. Angew. Chem., Int. Ed. Engl. 32 (1993) 666.

4. Uhlmann, E. and Peyman, A. Chem. Rev. 90 (1990) 543.

5. Milligan, J. F., Matteucci, M. D. and Martin, J. C. J. Med. Chem. 36 (1993) 1923.

6. Beaucage, S. L. and Iyer, R. P. Tetrahedron 49 (1993) 6123.

7. Garcia, A., Lambert, I. B. and Fuchs, R. P. P. Proc. Natl. Acad. Sci. USA 90 (1993) 5989.

8. Milhé, C., Dhalluin, C., Fuchs, R. P. P. and LeFévre, J.-F. Nucleic Acids Res. 22 (1994) 4646.

9. (a) Mao. B., Cosman. M.. Hingerty. B. E.. Broyde. S. and Patel, D. J. Biochemistry 34 (1995) 6226; (b) Mao, B., Cosman, M., Hingerty, B. E., Broyde, S. and Patel, D. J. Biochemistry 34 (1995) 16641.

10. (a) Eckel, L. M. and Krugh, T. R. Nature Struct. Biol. I (1994) 89; (b) Zhou, L., Rajabzadeh, M. and Cho, B. P. J. Am. Chem. Soc. 119 (1997) 5384.

11. Francois, J.-C., Thuong, N. T. and Hélène, C. Nucleic Acids Res. 22 (1994) 3943.

12. Leontis, N. B., Kwok, W. and Newman, J. S. Nucleic Acids Res. 19 (1991) 759.

13. Kadrmas, J. L., Ravin, A. J. and Leontis, N. B. Nucleic Acids Res. 23 (1995) 2212.

14. Rosen, M. A. and Patel, D. J. Biochemistry 32 (1993) 6563.

15. Rosen, M. A. and Patel, D. J. Biochemistry 32 (1993) 6576.

16. Koga, M., Moore, M. F. and Beaucage, S. L. J. Org. Chem. 56 (1991) 3757.

17. Koga, M., Wilk, A., Moore, M. F., Scremin, C. L., Zhou, L. and Beaucage, S. L. J. Org. Chem. 60 (1995) 1520.

18. Boiziau, C., Debart, F., Rayner, B., Imbach, J. and Toulmé, J.-J. FEBS Lett. 361 (1995) 41.

19. (a) Cazenave, C., Chevrier, M., Thuong, N. T. and Hélène, C. Nucleic Acids Res. 15 (1987) 10507; (b) Ganor, C., Rayner, B., Leonetti, J.-P. and Lebleu, B. Nucleic Acids Res. 17 (1989) 5107; (c) Boiziau, C., Kurfurst, R., Cazenave, C., Roig, V., Thuong, N. T. and Toulmé, J.-J. Nucleic Acids Res. 19 (1991) 1113; (d) AbdelAleem, H. A.-A., Larsen, E. and Pedersen, E. B. Tetrahedron 51 (1995) 7867.

20. Abdel-Rahman, A. A.-H., Ali, O. M. and Pedersen, E. B. Tetrahedron 52 (1996) 15311.

21. Khattab, A. F. and Pedersen, E. B. Acta Chem. Scand. 51 (1997) 1245.

22. Khattab, A. F. and Pedersen, E. B. Nucleosides Nucleotides. 17 (1998) 2351.

23. Caruthers, M. H. Acc. Chem. Res. 24 (1991) 278.

24. Mergny, J.-L., Boutorine, A. S., Garestier, T., Belloc, F., Rougée, M., Bulychev, N. V., Koshkin, A. A., Boursen, J., Lebedev, A. V., Valeur, B., Thuong, N. T. and Hélène, C. Nucleic Acids Res. 22 (1994) 920.

25. Rougée, M., Faucon, B., Mergny, J., Barcelo, F., Giovannangeli, C., Garestier, T. and Hélène, C. Biochemistry 31 (1992) 9269. 
26. Aramini, J. M., Kalisch, B. W., Pon, R. T., van de Sand, J. H. and Germann, M. W. Biochemistry 35 (1996) 9355.

27. Ali, O. M., Franch, T., Gerdes, K. and Pedersen, E. B. Nucleic Acids Res. 26 (1998) 4919.

28. Silver, G. C., Sun, J.-S., Nguyen, C. H., Boutorine, A. S., Bisagni, E. and Hélène, C. J. Am. Chem. Soc. 119 (1997) 263.

29. Ossipov, D. and Chattopadhyaya, J. Tetrahedron 54 (1998) 5667.

30. Zamaratski, E. and Chattopadhyaya, J. Tetrahedron 54 (1998) 8183.

31. Guckian, K. M., Schweitzer, B. A., Ren Rex, X.-F., Sheils,
C. J., Paris, P. L., Tahmassebi, D. C. and Kool, E. T. J. Am. Chem. Soc. 118 (1996) 8182.

32. Ouporov, I. V. and Leontis, N. B. Biophys. J. 68 (1995) 266.

33. Overmars, F. J. J., Pikkemaat, J. A., van der Elst, H., van Boom, J. H. and Altona, C. J. Mol. Biol. 255 (1996) 702 .

34. Rosen, M. A., Liver, D. and Patel, D. J. Biochemistry 31 (1992) 4002.

35. Welch, J. B., Walter, F. and Lilley, D. M. J. Mol. Biol. 251 (1995) 507.

Received December 28, 1998. 